\title{
A QUESTÃO DA HISTÓRIA E OS LAUDOS ANTROPOLÓGICOS: O CASO DA COMUNIDADE QUILOMBOLA RIO DOS MACACOS (BA)
}

\section{THE QUESTION OF HISTORY AND ANTHROPOLOGICAL REPORTS: THE CASE OF THE QUILOMBOLA COMMUNITY RIO DOS MACACOS (BA)}

\section{Flavio Luis Assiz dos Santos}

assiz25@yahoo.com.br

Doutor em Antropologia (UFBA), servidor do Instituto Nacional de Colonização e Reforma Agrária (INCRA)

ORCID: https://orcid.org/0000-0002-0143-7365

\section{RESUMO}

Os laudos antropológicos de identificação e delimitação territorial quilombola são produzidos a partir do manejo de um arsenal teórico-metodológico que opera necessariamente com categorias analíticas da história e da antropologia, num diálogo incessante e que está produzindo efeitos importantes tanto para as comunidades estudadas, como para estes dois campos disciplinares. Este artigo, que tomou como referência o laudo antropológico da comunidade quilombola de Rio dos Macacos, localizada entre os municípios de Simões Filho e Salvador (BA), analisou como se deu o diálogo entre esses dois campos de saber, articulado com uma discussão teórica sobre o tema.

Palavras-chave: laudos antropológicos; antropologia; história; quilombos.

\section{ABSTRACT}

The anthropological reports of quilombola territorial identification and delimitation are produced from the management of a theoretical-methodological arsenal that necessarily operates with analytical categories of history and anthropology, in an incessant dialogue that is producing important effects both for the studied communities and for these two disciplinary fields. This article, which made reference to the anthropological report of the quilombola community of Rio dos Macacos, located between the municipalities of Simões Filho and Salvador (BA), analyzed how the dialogue between these two fields of knowledge took place, articulated with a theoretical discussion about the theme.

Keywords: anthropological reports; anthropology; history; quilombos.

\section{INTRODUÇÃO}

Ao longo dos últimos 17 (dezessete) anos, a elaboração de laudos ou relatórios antropológicos ${ }^{1}$ foi incorporada como prática administrativa no Brasil para subsidiar ações fundiárias de reconhecimento e 
titulação dos territórios das comunidades quilombolas, municiando o Estado com informações antropológicas, etnográficas, históricas, culturais, socioeconômicas, geográficas, ambientais e documentais sobre esses grupos étnicos. A produção desses laudos/relatórios, que resultam de um trabalho pericial antropológico, é uma das exigências normativas para a operacionalização do art. 68, do Ato das Disposições Constitucionais Transitórias, da Constituição Federal de 1988, que garante aos remanescentes das comunidades dos quilombos o direito à propriedade definitiva das suas terras e atribui ao Estado o dever de emitir os respectivos títulos.

Desde 2003, com a publicação do Decreto 4.887, a elaboração dessas peças técnicas (laudos ou relatórios antropológicos) passou a ser produzida e disciplinada pelo Instituto Nacional de Colonização e Reforma Agrária (INCRA)², através de Instruções Normativas ("INs") ${ }^{3}$. A regular tramitação dos processos administrativos depende da existência desses laudos antropológicos ${ }^{4}$, que são elaborados a partir de uma pesquisa antropológica que opera com a categoria histórica "quilombos", fazendo com que este campo de trabalho suscite um profícuo debate relacionado ao diálogo disciplinar entre a Antropologia e a História.

A Bahia constitui-se como a unidade da federação que apresenta atualmente o maior número de comunidades quilombolas certificadas pela Fundação Cultural Palmares ${ }^{5}$ (FCP), totalizando 743 (setecentos e quarenta e três) certificações. Este é o estado que mais produziu laudos antropológicos, com 42 (quarenta e dois) laudos publicados de 2003 até 2019. Desses laudos, um dos que mais ganhou notoriedade foi o da comunidade quilombola de Rio dos Macacos, localizada entre os municípios de Simões Filho e Salvador, em virtude das relações conflituosas da comunidade com a Marinha do Brasil. Os conflitos vinham se desenrolando de forma intermitente ao longo de muitos anos, mas recrudesceu a partir de 2009 com a iniciativa da Marinha (Comando do $2^{\circ}$ Distrito Naval) de pedir a reintegração de posse das terras ocupadas pelos moradores da comunidade, sob a alegação de que as famílias ocupavam irregularmente área militar, sendo caracterizadas no processo judicial como "invasoras".

Em dezembro de 2011, o INCRA iniciou a elaboração do laudo antropológico da comunidade quilombola Rio dos Macacos, sob a responsabilidade da antropóloga Maria Ester Pereira Fortes ${ }^{7}$. O laudo, finalizado em julho de 2012, foi produzido em um contexto de conflitos, de urgência e de muita expectativa de todos os agentes envolvidos no processo quanto à identidade étnica daquele grupo e quanto ao território que o mesmo pleiteava. Assim, este artigo pautou-se na leitura deste laudo, no que se refere mais especificamente às questões que remetem à interlocução entre antropologia e a história. O objetivo foi analisar como se deu o diálogo entre esses dois campos de saber no processo de produção deste laudo, articulado com uma discussão teórica sobre o tema ${ }^{8}$. 


\section{ANTROPOLOGIA E HISTÓRIA: UM DIÁLOGO POSSÍVEL?}

Há em certa tradição antropológica um problema com o tempo e há na história um problema com a cultura. Assim, muitas pesquisas já foram orientadas a partir da pergunta: como os campos disciplinares da antropologia e da história podem se retroalimentar? $\mathrm{Na}$ antropologia um dos autores que mais se dedicou a essa questão foi Claude Lévi-Strauss, que tratou do tema em diversas de suas obras, entre elas "História e etnologia”, publicada em 1958 (LÉVI-STRAUSS, 2008); "Raça e história”, publicada em 1952 (LÉVI-STRAUSS, 1973); “O Pensamento Selvagem”, publicada em 1962 (LÉVI-STRAUSS, 1989), e a segunda "História e Etnologia”, publicada em 1983 (LÉVI-STRAUSS, 2004). Ele criticou a historiografia, acusando-a de ser um saber preso às contingências e centrado nos eventos de curta duração (RODRIGUES, 2009, p. 166) e defendeu o protagonismo da etnologia nas Ciências Sociais que, com seu método sincrônico, descrevia e formulava sobre as estruturas invariantes e de longa duração que caracteriza os fenômenos sociais. O autor critica o centralismo da história no mundo ocidental, o que seria uma espécie de "imperialismo entre nós apoiado sobre a suposta certeza de que a única forma de compreensão dos fatos humanos passa necessariamente pela recuperação do processo que fez com que chegassem a ser como são" (GOLDMAN, 1999, p. 226).

Lévi-Strauss busca romper com o pensamento evolucionista que marcou a origem da Antropologia no séc. XIX, com o pensamento historicista americano que superestimava a história (historicismo boasiano) e com o pensamento empiricista e a-histórico britânico que negligenciavam a história (funcionalismo de Radcliffe-Brown e Malinowski). Ele propõe uma análise estrutural em que o etnólogo deve se pautar por uma perspectiva mais globalizante e sistêmica, calcada mais no presente e não na diacronia (“imperialismo da História”), ressaltando mais as descontinuidades e especificidades sobretudo de ordem espacial (GOLDMAN, 1999). Para Lévi-Strauss, a estrutura social não é resultante apenas de dados empíricos (empiricismo), mas um sistema de relações sociais que o etnólogo revela através da construção de modelos teóricos que desvendam as estruturas profundas do sistema de funcionamento do social (estruturalismo).

Schwarcz (1999; 2005), ao analisar a fronteira entre antropologia e história no pensamento de Lévi-Strauss, afirma que este foi o mais radical dos antropólogos na proposição de um método sincrônico e que, para bem delimitar o campo da antropologia, pareceu fazer construir uma contraposição com a história, o que fez surgir dicotomias disciplinares que podem ser sintetizadas na ideia de que a história seria o reino da diacronia e a antropologia seria o reino da sincronia e da estrutura. No entanto, o que Schwarcz destaca é que o pensamento levistrussiano não negligenciou a história. Ao desenvolver, por exemplo, as noções de 
histórias estacionárias e cumulativas (depois redefinido como histórias quentes e frias), Lévi-Strauss estava reconhecendo que diferentes sociedades têm histórias diferentes, mas o que mudava era a maneira como cada uma delas se relacionava com a História. Para ele, algumas sociedades estão baseadas no tempo mítico, que percebe o seu passado quase como tempo presente, o passado coexistindo com o presente e não tem uma ideia de linha progressiva do tempo. Enquanto outras sociedades se representam a partir da história, as que se pensam a partir da mudança e da reiteração e elaboram a vida a partir da ideia de progresso, inovações e avanços e fazem da diacronia o motor do seu desenvolvimento (temporalidade linear). Ele cria um modelo binário para relacionar história e antropologia.

Lévi-Strauss (1989) faz uma crítica à “filosofia da história”, uma espécie de história da história, que coloca a narrativa diacrônica no centro. Para ele, o fato histórico não está posto, não é dado, pois é uma construção analítica tanto quanto os fatos objetos de estudo da antropologia. O fato histórico é sempre resultado de uma seleção. Tudo é a "história dos homens" e o trabalho do historiador e do antropólogo é muito parecido, pois ambos proporcionam um alargamento do conhecimento de determinada experiência. O autor não defende que existiriam "sociedades sem história", mas que existiriam diferentes historicidades, à medida que cada uma concebe distintamente a relação com o tempo passado, com o presente e com o futuro. Esta é a principal especificidade do pensamento levistraussiano sobre a história: a história passa a ser pensada a partir da diversidade (GOLDMAN, 1999).

Outro importante antropólogo que se dedicou ao tema da história foi Marshall Sahlins. Para ele, a história é ordenada de formas diferentes nas diversas sociedades. Estrutura e história não devem estar em lados opostos nas Ciências Sociais uma vez que a estrutura é de ordem histórica. Sahlins (1990) traz a perspectiva de que todos os povos têm história, mas que muitas vezes são invisibilizados. Não há sociedades perdidas no tempo e as mudanças históricas são orquestradas pelo modo de vida nativo e não só pelo contato externo.

Para Sahlins, as sociedades moldam a estrutura social a partir do que se está vivendo, sendo assim, a estrutura não é fixa. As pessoas agem de acordo com seus pressupostos culturais. Os eventos, que para ele não se restringem a um acontecimento, são fatos carregados de significados, são reavaliados e redefinidos na prática, nas ações dos sujeitos sociais e históricos.

[...] um evento não é somente um acontecimento no mundo; é a relação entre um acontecimento e um dado sistema simbólico. E apesar de um evento enquanto acontecimento ter propriedades "objetivas" próprias e razões procedentes de outros mundos (sistemas), não são essas propriedades, enquanto tais, que lhe dão efeito, mas a sua significância, da forma que é projetada a partir de algum esquema cultural. O evento é 
a interpretação do acontecimento, e interpretações variam (SAHLINS, 1990, p. 191).

A estrutura e os eventos se retroalimentam. De um lado, são transformados pela história e, de outro lado, transformam a própria história. Segundo Sahlins, a estrutura tem diacronia e sincronia ao mesmo tempo, numa superação do binarismo levistraussiano e das dificuldades do estruturalismo para explicar as mudanças históricas já que, para ele, a antropologia estrutural privilegia a sincronia em lugar da diacronia.

Estes e outros antropólogos influenciaram o pensamento no campo disciplinar da História, sobretudo na segunda metade do século $\mathrm{XX}$, que é marcado pela atração dos historiadores pela antropologia. O movimento conhecido como Escola dos Annales, fundado na França em 1929 por Marc Bloch e Lucien Febvre, buscou inovar a abordagem historiográfica combinando-a com os métodos das outras ciências humanas e rejeitando a ênfase predominante na política, na diplomacia e nas guerras. Os historiadores deste movimento propunham a ênfase nas pesquisas das estruturas de longa duração para pensar as transformações históricas. A chamada História Cultural (ou História das Mentalidades) fez florescer o diálogo entre a antropologia e a história. A partir da renovação historiográfica e da tendência cada vez mais difusa do uso dos métodos da antropologia, os historiadores passaram a investigar, por exemplo, os comportamentos e atitudes de grupos subalternizados ou pelo menos não privilegiados, como os camponeses e as mulheres, o feminismo e as culturas arruinadas pelo capitalismo (GINZBURG, 1991).

Para Darnton (1988, p. 13), a História Cultural tem uma forte tendência etnográfica. É o que ele chama de História das Mentalidades, que pode ser traduzida como História Cultural, “[...] porque trata nossa própria civilização da mesma maneira como os antropólogos estudam as culturas exóticas ", que se propõe a descobrir a cosmologia e as estratégias corriqueiras de pessoas comuns. O historiador deve explorar os significados de acontecimentos improváveis à analise tradicional da História, os pontos de vista pouco comuns, excêntricos e que, segundo ele, podem ser os mais reveladores de como se dão as estratégias da vida. As pessoas pensam corriqueiramente com as coisas ou com os materiais fornecidos pela sua cultura, como estórias, cerimônias, rituais, lendas etc.

De acordo com Darnton (1988), assim como os antropólogos, os historiadores também trabalham com áreas de opacidade e silêncio, e devem empreender esforços para elucidar a interpretação que as pessoas faziam dos fatos. Então, é sempre possível fazer perguntas novas ao material antigo, buscando "coisas boas para pensar". Ele afirma que o historiador deve ser sempre alertado para a falsa impressão de familiaridade com o passado e deve receber doses de choque cultural para captar a ideia da diferença e evitar os anacronismos. Darnton (1988) 
defende que o método antropológico da História tem um rigor próprio que começa com a premissa de que as impressões individuais ocorrem dentro de um idioma geral fornecido por nossa cultura e que o papel do historiador é descobrir a dimensão social do pensamento e extrair a significação de documentos, passando do texto ao contexto e voltando ao primeiro (DARNTON, 1988, p. 27). Portanto, tanto Darnton como Lévi-Strauss, oscilam entre a diacronia e sincronia e buscam reconhecer que o tempo é uma das dimensões da vida cultural. Há uma universalidade da história uma vez que a experiência da temporalidade é comum a todas as culturas, mas há também particularidades na forma como cada cultura empiricamente experimenta e vivencia a temporalidade (a passagem do tempo) e valoriza determinados eventos em detrimento de outros. Assim, tanto a cultura pode influenciar a história como a história pode influenciar a cultura.

Refletindo sobre o lugar da etnografia e da história na antropologia como meios complementares entre si para a reflexão sobre o "mesmo" e sobre o "outro", Jean e John Comaroff (2009) se notabilizaram pelos esforços teóricos de aproximação da antropologia com a história. Os autores pensam sobre o lugar da antropologia no mundo contemporâneo e apresentam uma proposta teórico-metodológica para uma antropologia crítica. A etnografia, assim como a história, e principalmente as duas juntas, seriam uma forma de conectar os fragmentos aos quais se pode ter acesso na pesquisa empírica a um contexto mais abrangente, histórica e culturalmente determinado, que lhes confere significado. Voltando-se principalmente para a crise epistemológica que se configura como crise de autoridade da etnografia enquanto método excepcionalmente revelador (que não se vale cegamente de técnicas padronizadas, que se apresenta mais com o fazer artístico), os autores apresentam uma argumentação complexa que leva à defesa desse método (que, segundo eles, apresenta uma "tensão produtiva", fruto da impossibilidade de separar o objeto do sujeito do conhecimento), associado à imaginação histórica.

Os Comaroff salientam que duas atitudes simultâneas são importantes: olharmos para o nosso próprio mundo como um problema (um lugar adequado para a pesquisa etnográfica), e que, para fazer valer esta intenção, desenvolvamos uma antropologia genuinamente historicizada. A etnografia é um modo historicamente situado de compreensão de contextos historicamente situados, cada um com seus próprios tipos de sujeitos e subjetividades, objetos e objetividade. A etnografia tem sido ademais, um discurso inescapavelmente ocidental. Assim, o apelo dos autores é para que a etnografia seja mais dialética e dialógica, situando os gestos, palavras e outras coisas mais dos "nativos" no interior dos sistemas de signos e relações, de poder e significado que os animam. Também o modo como a imaginação histórica funciona é culturalmente construído e assim também o historiador não é menos propenso a ler com olhos etnocêntricos. 
Estes autores consideram que a etnografia e história desenvolveram métodos complementares para uma boa antropologia e delineiam uma proposta metodológica para a uma antropologia histórica, fundamentada teoricamente. Essa antropologia deve mostrar que a história é construída: como as realidades se tornam reais, como as essências se tornam essenciais e como as materialidades se materializam. Mostrar que todas as ordens sociais existem no tempo, que são instáveis e dinâmicas e que a história é o movimento por meio do qual uma sociedade se revela como é (um processo no tempo). Mostrar que todas as sociedades têm uma historicidade endógena e que, portanto, não há "sociedades sem história”. E se a antropologia histórica pretende evitar as excentricidades e etnocentricidades do Ocidente, o indivíduo e o evento devem ser tratados como problemáticos em toda parte. Segundo eles, uma etnografia histórica deve começar por construir o seu próprio arquivo. Não pode se contentar com os cânones estabelecidos da prova documental, pois são tanto objetos com meios de investigação. Os antropólogos devem trabalhar tanto fora quanto dentro dos registros oficiais, tanto a partir quanto para além dos guardiões da memória.

A questão da memória neste contexto é fundamental e tornou-se um dos temas mais discutidos nos debates da História Cultural. O historiador Pierre Nora, uma das referências neste tema, salienta:

Memória, história: longe de serem sinônimos, tomamos consciência que tudo opõe uma à outra. A memória é a vida, sempre carregada por grupos vivos e, nesse sentido, ela está em permanente evolução, aberta à dialética da lembrança e do esquecimento, inconsciente de suas deformações sucessivas, vulnerável a todos os usos e manipulações, susceptível de longas latências e de repentinas revitalizações. A história é a reconstrução sempre problemática e incompleta do que não existe mais. A memória é um fenômeno sempre atual, um elo vivido no eterno presente; a história, uma representação do passado. Porque é afetiva e mágica, a memória não se acomoda a detalhes que a confortam; ela se alimenta de lembranças vagas, telescópicas, globais ou flutuantes, particulares ou simbólicas, sensível a todas as transferências, cenas, censura e projeções. A história, porque operação intelectual laicizante, demanda análise e discurso crítico. A memória instala a lembrança no sagrado, a história liberta, e a torna sempre prosaica. A memória emerge de um grupo que ela une, o que quer dizer, como Halbwachs o fez, que há tantas memórias quanto grupos existam; que ela é, por natureza, múltipla e desacelerada, coletiva, plural e individualizada. A história, ao contrário, pertence a todos e a ninguém, o que lhe dá uma vocação para o universal. A memória se enraiza no concreto, no espaço, no gesto, na imagem, no objeto. A história só se liga às continuidades temporais, às evoluções e às relações das coisas. A memória é um absoluto e a história só conhece o relativo (NORA, 1993, p. 09).

A memória, tida como reminiscências do passado, não diz respeito apenas ao passado, pois ela é acionada no presente; é um passado que é lembrado no presente, a partir dos interesses atuais de quem lembra. 
Neste sentido, a memória se refere a uma espécie de "banco de dados" disponível a um grupo que pode ser acessado a partir de estímulos diversos. Ela é dinâmica e aberta às contingências dos grupos humanos que podem fazer com que um determinado fato seja lembrado e valorizado enquanto outros sejam esquecidos ou silenciados. Nas Ciências Sociais, um dos autores mais renomados que discute o tema da memória é o sociólogo e filósofo Mauricie Halbawachs. Na sua obra "Memória Coletiva" (obra póstuma, publicada em 1950), este autor trata a memória como um fenômeno sociológico e não individual (como é tratado pela Psicologia); ela é um fenômeno coletivo, uma vez que está condicionada a um diálogo dos indivíduos em seu grupo. É a sociedade que ativa e reconhece as nossas memórias, que determina o que deve ser memorável, não sendo, portanto, uma experiência meramente individual subjetiva. As lembranças só têm significado quando são coletivizadas.

Não é suficiente reconstituir peça por peça a imagem de um acontecimento do passado para se obter uma lembrança. É necessário que esta reconstrução se opere a partir de dados ou de noções comuns que se encontram tanto no nosso espírito como no dos outros, porque elas passam incessantemente desses para aquele e reciprocamente, o que só é possível se fizeram e continuam a fazer parte de uma mesma sociedade. Somente assim podemos compreender que uma lembrança possa ser ao mesmo tempo reconhecida e reconstruída (HALBWACHS, 1990, p. 34).

Para o autor, a memória, cada vez que é reativada, está sujeita a mudanças. $\mathrm{O}$ ato de reconstrução a partir dos estímulos dos outros e do presente gera uma reativação constante, que é sempre uma nova versão, pois as interações sociais transformam as memórias dos grupos. Assim, a memória está sempre em movimento. Cada grupo tem a sua memória e o ato de lembrar depende de uma comunidade afetiva, de um envolvimento. $\mathrm{O}$ esquecimento acontece quando alguns indivíduos se desconectam do grupo e, portanto, se perdem as referências afetivas que fazem com que determinadas memórias sejam acionadas e valorizadas, ou seja, os indivíduos perdem a capacidade de rememorar, pois deixam de se identificar com certo "quadro social da memória".

Embora Halbawachs dê ênfase à memória coletiva, ele não nega a interação entre memória individual e coletiva. A memória coletiva é ativada em indivíduos específicos, mas sempre se manifesta enraizada dentro de um contexto. As memórias individuais estão em estreita relação com as lembranças de acontecimentos que tenham sido partilhados por um grupo, as lembranças individuais estão sempre identificadas com as lembranças do grupo (ou dos grupos) com o qual o indivíduo mantenha estreitas relações. A memória coletiva é uma espécie de base comum, sempre retroalimentada pelos testemunhos individuais e que criam um emaranhado de experiências e discursos sobre o passado. Para que uma memória coletiva se mantenha, é necessário que os indivíduos continuem dividindo e difundindo as mesmas recordações. 
A história opera num campo da representação do passado, é o "passado morto, geralmente reconstruído a partir de documentos, registros e relatos externos, de eventos não vividos, que constitui uma memória coletiva histórica oficializada, ideológica e que não guarda relações de continuidade com o passado dos grupos sociais. A memória é o "passado vivo", o passado sendo vivido, sendo reconstituído no presente e guarda, via de regra, relações de continuidade do passado com o presente dos grupos sociais. É a presentificação do passado. Vale ressaltar que a memória, ao reconstruir o passado, tem também um caráter político; traz a possibilidade de utilização política da memória que ressignifica $o$ passado de acordo com os interesses do presente e/ou para projetar um determinado futuro (embora ela não se reduza a um uso instrumental do passado).

Portanto, o que muitos autores criticam, é a centralidade em um modelo clássico de historiografia Ocidental, pautado pela cronologia e pela pesquisa documental. Para Palmié e Stewart (2016), por exemplo, este modelo está baseado em textos escritos, na linearidade temporal, na causalidade como modo padrão de explicação histórica, na crença em eventos contingentes e imprevisíveis, na evidência objetiva e limitada ao pensamento ocidental (historicismo) e defendem a constituição de uma antropologia da história calcada nos estudos etnográficos das formas de produção histórica não ocidentais. Para eles, a história diz respeito a qualquer tipo de relação com o passado em toda sua diversidade e trata das diferentes maneiras pelas quais as pessoas conceitualizam e avaliam moralmente o passado com relação ao presente (e ao futuro).

Assim sendo, "tudo é história" na medida em que qualquer forma de conhecimento e qualquer sociedade mantém uma relação com o passado. $\mathrm{O}$ argumento desses autores é que o historicismo referenda todo tipo de produção histórica acadêmica e as ações estatais. É como um sustento ideológico hegemônico no Ocidente, que tem afetado todo o mundo com a globalização. O desafio da antropologia da história é então apreciar "outros passados" deslegitimados ou silenciados pela historiografia acadêmica. É buscar uma forma de acessar uma historicidade que vai além do historicismo.

\section{ANTROPOLOGIA E HISTÓRIA NO LAUDO ANTROPOLÓGICO DE RIO DOS MACACOS}

Partindo da premissa que os laudos antropológicos "são bons para pensar", procurei então analisar como estas questões foram apresentadas e articuladas no laudo antropológico da comunidade quilombola Rio dos Macacos. Todo laudo antropológico para reconhecimento territorial quilombola se faz a partir do manejo de um arsenal teórico-metodológico que opera necessariamente com categorias analíticas da 
história e da antropologia, num diálogo incessante, que está produzindo efeitos importantes tanto para as comunidades estudadas, como para estes dois campos disciplinares. Tomei o texto do laudo antropológico como objeto de análise, observando a sua estrutura narrativa e as estratégias teórico-metodológicas da autora, com foco nas questões relacionadas à antropologia da história.

A primeira observação relevante é que o laudo inicia o seu percurso narrativo a partir de uma perspectiva sincrônica, com uma descrição e análise das situações do presente, mas sem abandonar a abordagem diacrônica. A descrição e a análise dos conflitos territoriais mais contemporâneos vividos pela comunidade sinalizam para a utilização da etnografia como método de produção dos dados da pesquisa que resultaram no laudo. Já na primeira página, a autora narra o episódio que fez eclodir a recente identificação étnica quilombola da comunidade.

Em 04 de novembro de 2011 a Associação dos Remanescentes do Quilombo Rio dos Macacos, em ofício, solicita do INCRA... que seja iniciado o processo de elaboração do RTID Relatório Técnico de Identificação e Delimitação $0^{9}$ do nosso território em vista do cumprimento da lei e efetivação da Delimitação, demarcação e titulação das terras legadas por nossos ancestrais e ocupadas tradicionalmente por nossa comunidade ${ }^{10}$. O ofício acrescenta também que a comunidade ...vive situação de grave conflito e por isso demanda a necessidade de urgente atuação do INCRA.

Esta solicitação deu início ao processo INCRA No54160.003162/201157, para a instauração dos procedimentos relativos à regularização do território da comunidade. O conflito a que se refere o ofício mencionado vinha se desenrolando de forma intermitente ao longo de muitos anos mas sua agudização se deu com a iniciativa do Comando da Base Naval Marinha de pedir a reintegração de posse das terras ocupadas pelos moradores da comunidade, pedido este que desembocou nos processos em curso na Justiça Federal 2009.33.00.016792-4; 2242598.2010.4.01.3300; 22426 83.2010.4.01.3300, a partir de 04 de outubro de 2009, em que é autora a União Federal e constam como réus trinta moradores da comunidade. Em novembro de 2010 o juiz responsável defere a tutela antecipada para determinar aos réus a desocupação das áreas, no prazo de 120 dias, sob pena de retirada compulsória.

Em dezembro daquele mesmo ano, representantes de diversas secretarias de Estado foram chamados para encontrar uma solução para a questão, uma vez que as famílias acionadas viviam em condições econômicas e sociais de extrema fragilidade. No mesmo mês foi realizada pela SEDUR - Secretaria de Desenvolvimento Urbano da Bahia, uma primeira visita técnica à comunidade Rio dos Macacos, para reconhecimento do local do conflito da população envolvida. A seguir a SEAGRI - Secretaria da Agricultura, Irrigação e Reforma Agrária da Bahia, a CONDER - Companhia de Desenvolvimento Urbano do Estado da Bahia, a SAEB - a Secretaria de Administração do Estado da Bahia e Prefeitura Municipal de Simões Filho realizaram estudos socioeconô- 
micos, para o levantamento das políticas públicas habitacionais que pudessem melhor atender às famílias que estavam sofrendo ordem de despejo. O grupo de trabalho intersetorial, sob coordenação da SEDUR, realizou também um levantamento fundiário e ambiental da região, objetivando encontrar possíveis áreas do entorno onde relocar estas famílias. Pedidos de alargamento do prazo de retirada dos moradores foram feitos com este objetivo, que parecia consensual: encontrar um lugar adequado para o reassentamento do grupo (FORTES, 2012, p. 03-04).

Com a iminência do despejo ${ }^{11}$, a comunidade buscou apoio de diversas organizações e passou a denunciar que há décadas sofria violações à integridade física e moral de seus membros, restrições à liberdade de ir e vir, impedimento de acesso a serviços básicos de educação e saúde, violação à privacidade e cerceamento ao desempenho de atividades econômicas de subsistência, como, por exemplo, a plantação de roças e criação de pequenos animais. Essas supostas ações seriam cometidas pela Marinha como forma de desagregar a comunidade e obrigá-los a desocupar a área. Como resistência, uma das estratégias da comunidade consistiu em fazer manifestações em frente à Base Naval de Aratu' ${ }^{12}$, no período em que a então Presidenta Dilma Rousseff estava lá hospedada em férias, o que fez o caso ganhar forte repercussão midiática.

A condição de ameaça que se consolidava com a decisão judicial pelo despejo foi, deste modo, o gatilho que disparou a emergência da consciência identitária entre os moradores de Rio dos Macacos. Isto culminou com o autorreconhecimento da comunidade como remanescente das comunidades dos quilombos e sua certificação pela Fundação Cultural Palmares, em 23 de setembro de 2011. A partir do reconhecimento oficial daquela comunidade como quilombola, a perspectiva de reassentamento compulsório do grupo foi substituída pela esperança de regularização fundiária do território quilombola, para a qual a elaboração de um laudo antropológico era necessária e urgente ${ }^{13}$.

A "situação de perícia" (Arruti, 2006) que estava posta naquele contexto era a de uma série de discursos e imaginários sobre a possibilidade de existência de um "quilombo" dentro dos limites de uma área militar. Qual era o tempo daquela ocupação? Seriam os quilombolas invasores de uma área de segurança nacional? Como a Marinha havia permitido isso acontecer? A Marinha do Brasil em diversas reuniões e em documentos oficiais chamava os moradores de Rio dos Macacos de "os invasores" ou os "ditos quilombolas". Todas as expectativas eram que o laudo antropológico "provasse que Rio dos Macacos era um quilombo", e que a ocupação quilombola era anterior à chegada da Marinha na área ${ }^{14}$.

A autora então dedicou a primeira parte do laudo para fazer uma revisão bibliográfica do termo "quilombo", buscando as referências teóricas que apontam para a ressemantização do conceito histórico de "quilombo", associado à ideia de fuga e isolamento (REIS, 1996; ALMEIDA, 2006; TRECANI, 2006; ABA, 1994). Outras referências teóricas impor- 
tantes foram relacionadas às teorias da etnicidade, que compreendem as comunidades quilombolas como grupos étnicos constituídos a partir de fenômenos situacionais, contrativos e relacionais; da manutenção das fronteiras étnicas (BARTH, 2000; CUNHA, 1985, 2009; CARDOSO DE OLIVEIRA, 2006).

É, portanto, a partir da assunção de uma identidade específica, que estas comunidades orientam seu discurso, encaminham suas demandas por direitos ou enfrentam as pressões de uma lógica de produção e apropriação dos recursos naturais diversa daquela que orienta o seu cotidiano e da qual se percebem excluídos. A etnicidade torna-se, portanto, o caminho privilegiado através do qual estes grupos se representam e se fazem ouvir (FORTES, 2012, p. 11).

Mas não foi possível escapar da "Filosofia da História" de que fala Lévi-Strauss, que coloca a narrativa diacrônica no centro. Afinal de contas, o enfrentamento que estava por vir era com a poderosa Marinha do Brasil, que recorria a um determinado discurso historiográfico para afirmar ser impossível existir ali, tão perto da capital (Salvador) e dentro das suas terras (de segurança nacional), um quilombo. A estratégia da antropóloga foi então recorrer à História do Recôncavo baiano, berço das plantations nas Américas, uma região formada por vales, várzeas, ilhas, ilhotas, mangues e planaltos próximos ao mar e costeando a Baía de Todos os Santos, com forte presença dos Engenhos de cana-de-açúcar implantados no período colonial e dependentes da mão de obra escrava. Essa região tornou-se um território predominantemente negro e carregado de histórias e tradições ligadas à cultura afro-brasileira e estes engenhos são até hoje uma referência fundamental (até mesmo devido à proximidade geográfica e presença na paisagem) da própria comunidade e da população local.

Numa perspectiva de uma etnografia histórica (COMAROFF, 2009), a autora "não se contentou com os cânones estabelecidos pela prova documental". Para acessar o passado, a antropóloga se valeu, como estratégia teórico-metodológica, das entrevistas e da observação participante, como forma de captar a memória coletiva do grupo e da consulta a vários tipos de fontes documentais. Ela utilizou, por exemplo, documentos do acervo pessoal das famílias quilombolas (registros de batismo, carteiras de identidade, recibos, cartas, fotografias de família, registros cadastrais etc.), dando relevância histórica e etnográfica a estes documentos. Os mapas, imagens de satélite, croquis e registros fotográficos (produzidos pela própria autora, pelos quilombolas ou por outras instituições públicas, inclusive a própria Marinha) também foram documentos acionados/valorizados na etnografia. No laudo, percebem-se os esforços da pesquisadora em, a partir das referências obtidas pelo recurso à memória dos quilombolas, buscar consultar e analisar as muitas fontes documentais existentes sobre o Recôncavo, para confirmar e/ou confrontar com os relatos orais, algumas vezes evidenciando as lacunas 
da documentação que foram "preenchidas" pela memória coletiva. A autora pesquisou no Arquivo Público do Estado da Bahia (escrituras, inventários, testamentos), em cartórios, arquivos das paróquias locais, em bibliotecas e nos autos de processos judiciais. Os dados secundários foram obtidos em diversas obras de historiadores reconhecidos, servindo de respaldo teórico e base para a construção do laudo. Cumpre registrar que não houve a participação de nenhum/a historiador/a compondo a equipe técnica que deu suporte à elaboração da perícia. Com efeito, as considerações historiográficas presentes no laudo foram pesquisadas e elaboradas pela própria antropóloga perita.

Frente ao seu referencial teórico, que ressemantizou a categoria histórica quilombo, a etnografia caminhou no sentido de construir uma linha de continuidade histórica entre os antigos engenhos e a atual comunidade quilombola de Rio dos Macacos. A antropóloga percebeu que as ruínas e chaminés desses engenhos eram como uma espécie de "lugares de memória” (NORA, 1993) ${ }^{15}$ importantes dos quilombolas e então investiu numa pesquisa diacrônica e traçou um histórico da ocupação da região do recôncavo baiano para situar a formação da comunidade de Rio dos Macacos.

A ação da História pode mudar as formas de organização de um dado grupo e mesmo suas características culturais podem se alterar. Não obstante, a dicotomia entre membros e estranhos continua. O foco de análise se desloca do conteúdo cultural para os limites sociais estabelecidos pelo grupo e mantidos através do tempo. Dessa nova perspectiva, são considerados remanescentes de quilombos grupos cuja trajetória é fruto de um processo histórico de resistência ao sistema escravocrata e suas consequências. $O$ termo passa a denominar não apenas os grupos constituídos por "negros fugidos", mas os que formados em terras doadas, compradas, concessões feitas pelo Estado, áreas apossadas, ou ainda nos casos em que os descendentes de grandes proprietários mantiveram a propriedade aforando a terra para as comunidades (FORTES, 2012, p. 12).

Na região, há registros históricos da existência de vários engenhos de cana, sendo que a referência mais marcante no histórico de Rio dos Macacos foi o Engenho e a Usina de Aratu, localizados nas antigas freguesias de Salvador ${ }^{16}$ (existentes até meados do séc. XIX): de São Miguel de Cotegipe e de Nossa Senhora do Ó de Paripe. De acordo com a autora do laudo, "esta unidade produtiva desempenhou um importante papel na organização econômica e fundiária desta região e é a ela que nos remetem as memórias mais profundas dos moradores de Rio dos Macacos" (FORTES, 2012). A partir da consulta a inventários de antigos proprietários de engenhos e da bibliografia existente sobre a história do Recôncavo, foi possível deduzir que o engenho Aratu era próspero, com muitos escravos, o que necessitava de muitas terras. Ao redor dele havia fazendas que forneciam não apenas matéria-prima (cana-de-açú- 
car), mas também lenha para as caldeiras, gado para os carros de bois e farinha, sobretudo para a alimentação dos escravos.

Outra referência importante da bibliografia sobre o Recôncavo foi a formação da pequena produção agrícola, como o cultivo do café, fumo, mandioca para produção de farinha que se desenvolveu às margens e até mesmo dentro das terras das grandes propriedades rurais na região. Essa pequena produção familiar, que exigia poucos braços, era responsável pela produção de alimentos e ajudou a diversificar a produção agrícola numa economia predominantemente monocultora.

Figura 1 - "Lugar de Memória”: torre remanescente da Usina de Aratu

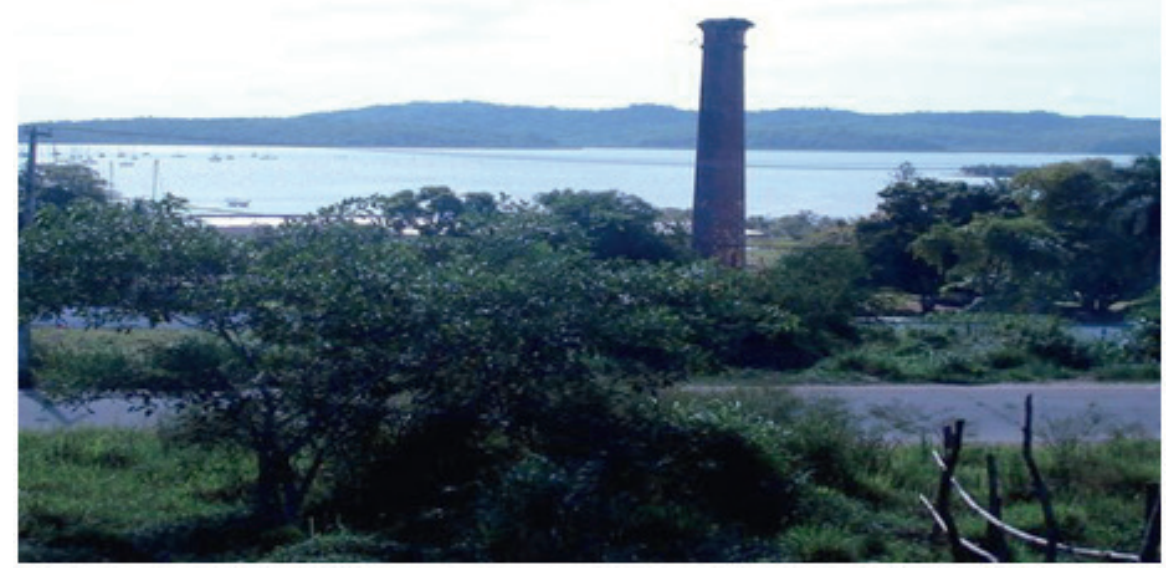

Foto: Maria Ester Pereira Fortes, em dezembro de 2011.

Fonte: Laudo Antropológico da Comunidade Quilombola Rio dos Macacos (2012).

Portanto, é num espaço regional, historicamente cenário de grandes plantações de cana-de-açúcar e de pastagens de gado, que a história da comunidade Rio dos Macacos se inicia na narrativa do laudo. As memórias mais antigas fazem menção às Fazendas Aratu, Meireles e Macacos, e muito provavelmente se referem a eventos ocorridos entre as décadas de 1920 e 1930. As referências à Fazenda Aratu e à Fazenda Meireles se misturam na memória dos moradores da comunidade. Isso se explica pelo fato de as fazendas, que são confinantes, não terem possuído cercas entre suas divisas até a chegada da Marinha e em função de diversos trabalhadores da comunidade prestaram serviços anteriormente para os seus proprietários. Este é o caso de Severiano dos Santos, conhecido como "Severo Rabeca", que nasceu em 1910 na Fazenda Meireles (atualmente área da Marinha) e que viveu nela até falecer, há aproximadamente oito anos. 
Figura 2 - Fazendas Aratu, Meireles e Macacos

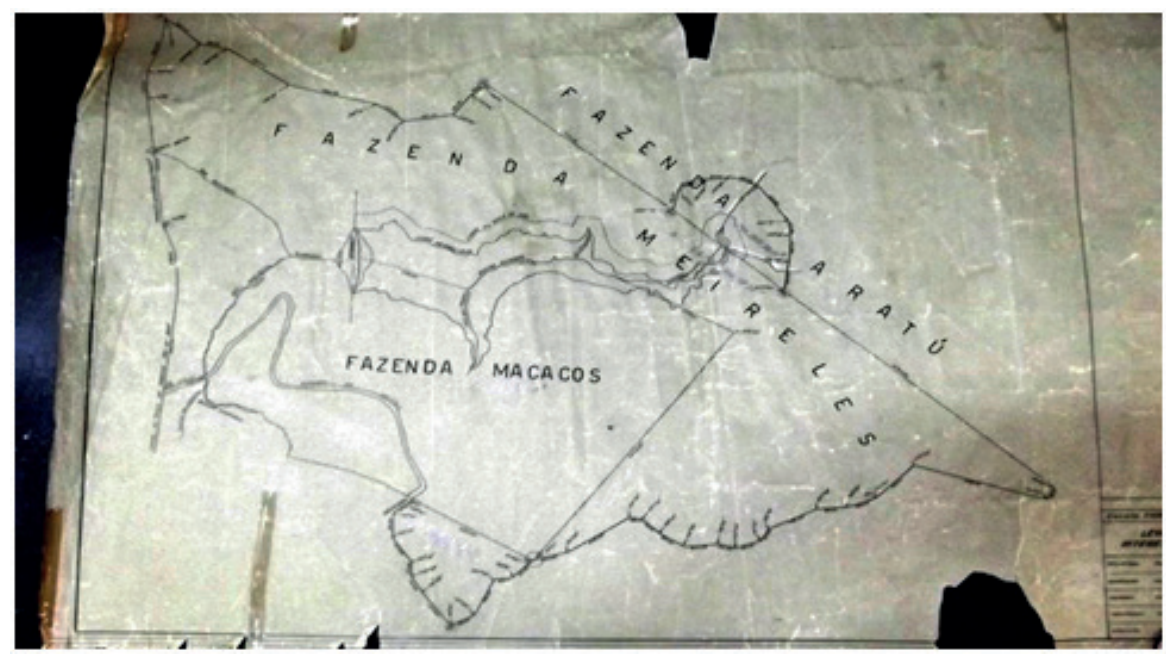

Fonte: Arquivo cartográfico da Base Naval de Aratu. Reproduzido no Laudo

Antropológico da Comunidade Quilombola Rio dos Macacos (2012)

Estas três fazendas (Aratu, Meireles e Macacos) abasteciam o engenho Aratu. Com a decadência do Engenho Aratu, por volta dos anos de 1930, as fazendas foram vendidas, desmembradas ou abandonadas, mas muitos dos descendentes dos escravos que trabalharam para a Usina Aratu permaneceram nessas terras.

Até o momento não foram encontradas referências documentais ou bibliográficas sobre o funcionamento e a desativação da Usina Aratu. Fontes orais, no entanto, nos informam de que esta usina teria fechado suas portas em meados dos anos 1930. Esta unidade produtiva desempenhou um importante papel na organização econômica e fundiária desta região e é a ela que nos remetem as memórias mais profundas dos moradores de Rio dos Macacos (FORTES, 2012, p. 21).

\section{Conforme a autora do laudo,}

Mesmo depois da paralisação de suas atividades produtivas, a Usina continuou a ser uma referência importante para os que permaneceram vivendo nas terras ao seu redor, como foi o caso dos moradores da comunidade de Rio dos Macacos. Com o fechamento da Usina, no entanto, a história prosseguiu o seu curso e outras referências foram fundamentais para construir o que hoje é a Comunidade Remanescente de Rio dos Macacos e para o que a chegada da Marinha e estas terras constituiu, sem sombra de dúvidas, um outro marco fundante (FORTES, 2012, p. 26).

A memória coletiva em Rio dos Macacos está vinculada às histórias de vida do trabalho na Usina Aratu e às terras do seu entorno. A autora deu visibilidade a algumas dessas histórias. Uma delas foi a de Manoel "Vigia", como era conhecido Manoel de Jesus, nascido em 1900 e falecido em 1996, e um dos antepassados mais lembrados pela comunidade. Ele era quem cuidava das terras da Fazenda Aratu como "vigia" dos ar- 
mazéns e todos os seus filhos nasceram nestas terras. O filho de Manoel "Vigia" conhecido como Barro Leite (Antônio dos Santos) morreu em 2010 aos 75 anos e está arrolado no processo que a Marinha move contra a comunidade. A sua viúva, D. Neném, vive até hoje no território e é uma espécie de guardiã da memória da comunidade.

Outra família importante nas memórias é a dos Rabeca (apelido relacionado à tradição da família com o trabalho em madeira, que foi incorporado oficialmente no nome de vários membros da família). Severiano dos Santos, ou Severo, como era conhecido na comunidade, nasceu em 1910 e morreu em 1994 nessas terras e trabalhava como vaqueiro e administrador, antes na Fazenda Aratu e depois na Fazenda Meireles. Seu irmão Lázaro, nascido em 1922, também viveu toda a sua vida neste lugar e morreu em 2001. Várias famílias atuais de Rio dos Macacos descendem dos Rabeca: Osvaldo, filho mais velho de Severo; José Catarino; Albertina; José Araújo dos Santos, o filho mais novo de Severo. Todos os descendentes viveram ou vivem no território. Os que saíram foi por causa da proibição da Marinha para construção de novas casas, mas moram hoje em locais próximos do território: Paripe (bairro da periferia de Salvador) ou Alto dos Macacos (localidade vizinha ao território que foi formada basicamente pelos moradores que foram expulsos do território pela Marinha).

A Fazenda Macacos era ocupada por vários posseiros que cultivavam em toda a área, como Crispiniano Ramos das Neves, nascido em 1941 na Fazenda e que recordou o nome de várias outras famílias que viveram na Macacos. Seu Antônio Góes dos Santos (Antônio Branco) nasceu em 1940, chegou à fazenda Macacos há sessenta anos e contou que havia um pequeno povoado de moradores onde hoje é a Vila Naval. Uma das moradoras mais antigas da comunidade, Maria de Souza Oliveira, 84 anos, também nasceu e foi criada na Macacos. Os filhos dela, Orlando (60 anos), Osvaldo (57 anos), José (54 anos), Olinda (53 anos) e Luiz (50 anos) vivem todos na mesma casa da mãe, pois suas casas caíram e a Marinha não autorizou a reconstrução. Ela tem como referência mais marcante um dos antigos proprietários da Fazenda, Coriolano Navarro Bahia e relata que seu pai trabalhou para este fazendeiro como "escravo", e com a morte do pai o próprio Coriolano adotou a família dela. Quando Coriolano deixou a Fazenda, esta foi arrendada para outras pessoas, mas os trabalhadores permaneceram e continuaram com as plantações e fazendo carvão. Com a chegada da Marinha, D. Maria conta que foi a parteira da primeira criança filha de um oficial e que prestava serviços também de lavadeira, cozinheira e benzedeira, sinalizando que havia um reconhecimento da Marinha da presença deles na área.

A autora descreve que Rio dos Macacos se organizou em torno de vários núcleos familiares que se estabeleceram nestas terras como pequenos agricultores. A sociabilidade está marcada pelas relações de reciprocidade e solidariedade, como aponta: 
[...] entre os membros de um mesmo núcleo familiar, as trocas e ajudas mútuas são bastante intensas: trocam-se serviços no cuidado com a casa e as crianças entre as mulheres, alimentos e decisões coletivas quanto ao uso e os cuidados com a água ou com outros recursos disponíveis no território. Entre núcleos familiares distintos, no entanto, ocorrem a partilha de recursos distribuídos desigualmente no território: água, áreas de pastagem, madeira para usos diversos ou plantas medicinais da flora local. O cuidado com os caminhos, o reparo ou mesmo a construção de uma casa também podem demandar a ajuda de vizinhos (FORTES, 2012, p. 85).

Os critérios de pertencimento dos moradores de Rio dos Macacos não estão vinculados à origem em um mesmo tronco familiar, mas em função dos vínculos das famílias com a área tradicionalmente ocupada e de envolvimento no esforço comum de permanência no território. Assim, são também membros da comunidade as pessoas que estabeleceram laços duradouros através de parentesco e vizinhança. A convivência com um inimigo comum - a Marinha - fortaleceu os laços comunitários e estabeleceu uma identidade coletiva contrastiva.

Vários fatos que marcaram o processo de (des)territorialização da comunidade adquiriram no laudo o status de "eventos" (SAHLINS, 1990) que ganharam relevância histórica. Na década de 1960, as terras da Fazenda Aratu foram desapropriadas pelo Governo do Estado da Bahia para a implantação do Complexo Industrial de Aratu (CIA), administrado pela SUDIC (Superintendência de Desenvolvimento Industrial e Comercial da Bahia), o que provocou um deslocamento dos moradores para as fazendas vizinhas Meireles e Macacos. No final da mesma década, a Marinha do Brasil se tornou proprietária da Fazenda Meireles (com o objetivo de construir a Barragem dos Macacos) e deu início ao cercamento do imóvel, o que provocou um rompimento da ligação entre os trabalhadores remanescentes da fazenda Aratu e os trabalhadores da Fazenda Meireles. Já a Fazenda Macacos (desmembrada da Fazenda Meireles), que pertencia à Prefeitura de Salvador desde 1916 (adquirida como pagamento por dívida de impostos), é doada à Marinha do Brasil, em 1960, sem o conhecimento dos moradores e sem indenização (muito embora a Prefeitura de Salvador reconhecesse a existência das famílias e consignasse no termo de doação que a Marinha deveria indenizar os ocupantes da Fazenda).

Assim, a antropóloga explica que a comunidade de Rio dos Macacos "[...] assistiu à chegada da Marinha em porções diversas do seu território a cada vez e da SUDIC, em um período quase simultâneo" e que

[...] os deslocamentos dos moradores dentro do território ou para fora dele, obedeceram ao avanço deste processo que, originário de uma outra ordem, desconsiderava a legitimidade de uma ocupação que, mesmo estando já presente naquele lugar, estava invisível aos olhos daquelas instituições (FORTES, 2012, p. 59). 
Com efeito, as 67 (sessenta e sete) famílias da comunidade quilombola estão localizadas em terras que pertencem legalmente hoje, em grande parte, à Marinha do Brasil. A chegada da Marinha na região remonta à Segunda Guerra Mundial, quando construiu a Base Naval de Aratu. Nas décadas de 1950/1960, ela promoveu a construção da Barragem dos Macacos na área das fazendas Meireles e Macacos, para abastecimento da Base Naval. Com isto, os moradores das fazendas que viviam como posseiros foram deslocados dentro do próprio território ou expulsos. A represa da barragem alterou a configuração espacial da comunidade, pois provocou o reassentamento compulsório das famílias, dificultou o acesso entre os sítios e a sociabilidade entre os moradores.

Contudo, as famílias continuavam tendo acesso às principais áreas destinadas a moradia e roça no interior da Fazenda Macacos. Mas o evento mais marcante foi a construção da Vila Naval da Barragem, na década de 1970, uma vez que esta foi construída onde havia a moradia de cerca de 50 famílias quilombolas. Assim, houve um novo e mais traumático deslocamento das famílias para a porção oeste do território - do lado de lá da barragem, no local onde ainda hoje está a maior parte das famílias - e muitas saíram do território. Várias práticas tradicionais da comunidade, como festas, candomblé, sambas de caboclo, foram desautorizadas. As famílias que resistiram passaram a vivenciar um constante processo de enfrentamento com a Marinha.

Após a construção da Vila Naval da Barragem, os moradores viveram um período de certa tranquilidade, uma vez que a Marinha cadastrava as famílias e permitia o cultivo das roças, pesca na barragem, plantio dos pomares e o extrativismo. No laudo são apresentadas cópias de documentos emitidos pela Marinha, que autorizam alguns moradores a transitar pela Vila Naval em direção às suas casas. Há relatos também de que alguns quilombolas, a exemplo do Sr. Antônio Alexandrino, que vendiam para os oficiais parte da produção de suas roças, além de prestar serviços como pedreiros e carpinteiros. A descrição do território feita pela autora aponta para a existência de diversos elementos inscritos na paisagem e nas lembranças dos moradores que evidenciam as marcas do trabalho individual, familiar e coletivo que construíram o território quilombola, constituído, portanto, como "lugares de memória": a rede de caminhos que interliga os diversos núcleos familiares entre si e com os lugares de uso partilhado; a quantidade inumerável de árvores frutíferas que cobre grande parte das terras ou que estão integradas à vegetação nativa; o estreito conhecimento da geografia do lugar; as ruínas de antigas moradias; os vestígios das antigas roças; os vestígios de antigas casas de farinha; lugares de coleta de madeira, ervas e extrativismo de dendê e licuri. Um dos exemplos mais significativos descritos no laudo da relação da comunidade e o ambiente diz respeito às fontes de água. A autora coloca que todos os rios e riachos estão fortemente gravados nas memórias dos quilombolas mais velhos e muitos deles levam o nome dos moradores que os utilizam ou utilizaram. 
A narrativa da trajetória de resistência da comunidade a estes eventos traumáticos teve grande peso na estratégia argumentativa da autora. Ela descreve que com a chegada da Marinha se estabeleceu entre as famílias que resistiam em Rio dos Macacos um "inimigo comum” e conclui que

[...] não podemos minimizar, portanto, a importância da Marinha na constituição mesma da identidade desta comunidade e na constituição de seu território, pois foi o constante "reagir" no tempo a esta presença que determinou o modo como seus membros organizaram suas vidas. Onde e como construir suas casas de moradia, onde o plantar e buscar recursos básicos para a sobrevivência, como traçar as rotas e caminhos pelo território, foram escolhas determinadas em função da imposição desta nova ordem sobre a vida de cada uma destas famílias (FORTES, 2012, p. 59).

Constitui-se, desta forma, um verdadeiro território de confinamento. Portanto, a emergência da identidade étnica em Rio dos Macacos resultou da interação, do confronto e da luta que o grupo travou dentro de um contexto social mais amplo (sobretudo a partir das relações estabelecidas com a Marinha) "para circunscrever e fazer reconhecer o lugar de dentro do qual, nesse contexto, elas esperavam se fazer ouvir" (FORTES, 2012, p. 101). Com a ameaça de expulsão do território em que vivem, os moradores de Rio dos Macacos perceberam a necessidade do reconhecimento de sua identidade específica e fizeram (e fazem) uso político deste atributo, estabelecendo uma contrastividade e delimitando as fronteiras do grupo. Para tanto, recorreram à sua origem negra e ao trabalho na cultura açucareira; ao conhecimento acumulado ao longo de gerações, estreitamente vinculado ao território e suas peculiaridades ambientais e ao trabalho como pequenos agricultores e coletores (FORTES, 2012).

A abordagem teórico-metodológica do laudo antropológico de Rio dos Macacos pode ser encarada, ao meu ver, como um exercício de submeter a história à etnografia. A autora, apoiando-se no pensamento de Reis e Gomes (1996) e de Arruti (2006), salienta que noção de Quilombo histórica, associada "[...] quase invariavelmente, à ideia de comunidades de negros fugidos, embrenhados nas matas e isolados do restante da sociedade para melhor proteger sua liberdade" (FORTES, 2012, p. 109), não se aplica ao caso de Rio dos Macacos. Ela destaca que

[...] as pesquisas históricas das últimas décadas vêm demonstrando, no entanto, que este isolamento não era condição essencial para a sobrevivência destas comunidades. Em diversas situações, estas comunidades permaneciam próximas às vilas, fazendas ou cidades, congregavam escravos fugidos e libertos, brancos, indígenas e outras figuras sociais e estabeleciam com estas vilas, fazendas e cidades trocas comerciais e mesmo 'afetivas' (FORTES, 2012, p. 109-110).

E salienta que, a exemplo do que pode ser observado na trajetória da comunidade de Rio dos Macacos, é a busca pela autonomia que es- 
tabelece uma linha de continuidade entre estas comunidades formadas a partir da fuga de escravos e as comunidades negras a que chamamos hoje de quilombolas (FORTES, 2012).

A Comunidade de Rio dos Macacos luta pelo direito de permanecer como uma comunidade autônoma dentro do território que ocupa há várias décadas. Seus moradores se estabeleceram neste território como trabalhadores e pequenos lavradores; não há qualquer dúvida, entretanto, de que dentro de condições bastante adversas, consolidaram nele uma rede de parentesco e de afinidade que fortalece os laços sociais entre seus membros, construíram uma relação de dependência e de interação com o território que ocupam e, a partir deste mesmo território, constituíram um corpo de conhecimento sobre o mundo natural e social que os envolve (FORTES, 2012, p. 110).

A autora do laudo, então, respaldada pela pesquisa etnográfica, buscou problematizar a noção clássica de quilombo, apresentada dentro de uma política a princípio voltada para o passado, que foi se transformando, de modo a ganhar novos significados no presente e, com isso, permitir pensar projetos para o futuro. Ela buscou apreender como aquela comunidade ressignificou o conceito de quilombo e se reconheceu como uma "comunidade quilombola". Como vimos, a memória social da comunidade remete ao período da escravidão em virtude dos antepassados de vários troncos familiares terem trabalhado como escravos na Usina Aratu e nas fazendas dos arredores (Macacos, Meireles e Aratu) e, após a decadência da Usina, os seus descendentes terem permanecido nas terras se submetendo às relações de trabalho análogas às do período da escravidão e resistindo às diversas tentativas de expropriação.

Com base nesta argumentação, a autora propôs uma delimitação do território de Rio dos Macacos, que se constituiu num processo de identificação das fronteiras e dos limites das terras ocupadas e apropriadas (no passado e no presente) por esse grupo étnico. O território delimitado no laudo constitui 300 hectares e compreende a área da Fazenda Macacos e da Fazenda Meireles que, embora estejam hoje legalmente sob o domínio da Marinha do Brasil ${ }^{17}$, são, segundo as informações etnográficas expostas no laudo, áreas que poderiam ser legitimamente pleiteadas pela comunidade para a regularização de seu território étnico, conforme as disposições legais em vigor no País.

O laudo não deixou de reconhecer que a Marinha é proprietária atual das terras, mas todo o argumento foi para mostrar que a formação da comunidade é anterior à presença da Marinha na área e que haveria uma profundidade histórica que justificaria a regularização fundiária da área como remanescente de quilombos, sendo, portanto, necessária uma compatibilização dos interesses por parte do Estado na área. Após a publicação do laudo e diversas negociações entre várias instituições dos Governos Federal e Estadual, sob a mediação da Casa Civil da Presidência da República, a ordem de despejo foi suspensa e a comunidade 
continua empreendendo diversas ações para dar visibilidade a sua luta e a sua "história"18. Em julho de 2020, o INCRA concedeu à comunidade o título de domínio pleno coletivo e pró-indiviso sobre terras públicas federais referente a 97 (noventa e sete) hectares do seu território ${ }^{19}$.

Figura 3 - Mapa do Território Delimitado

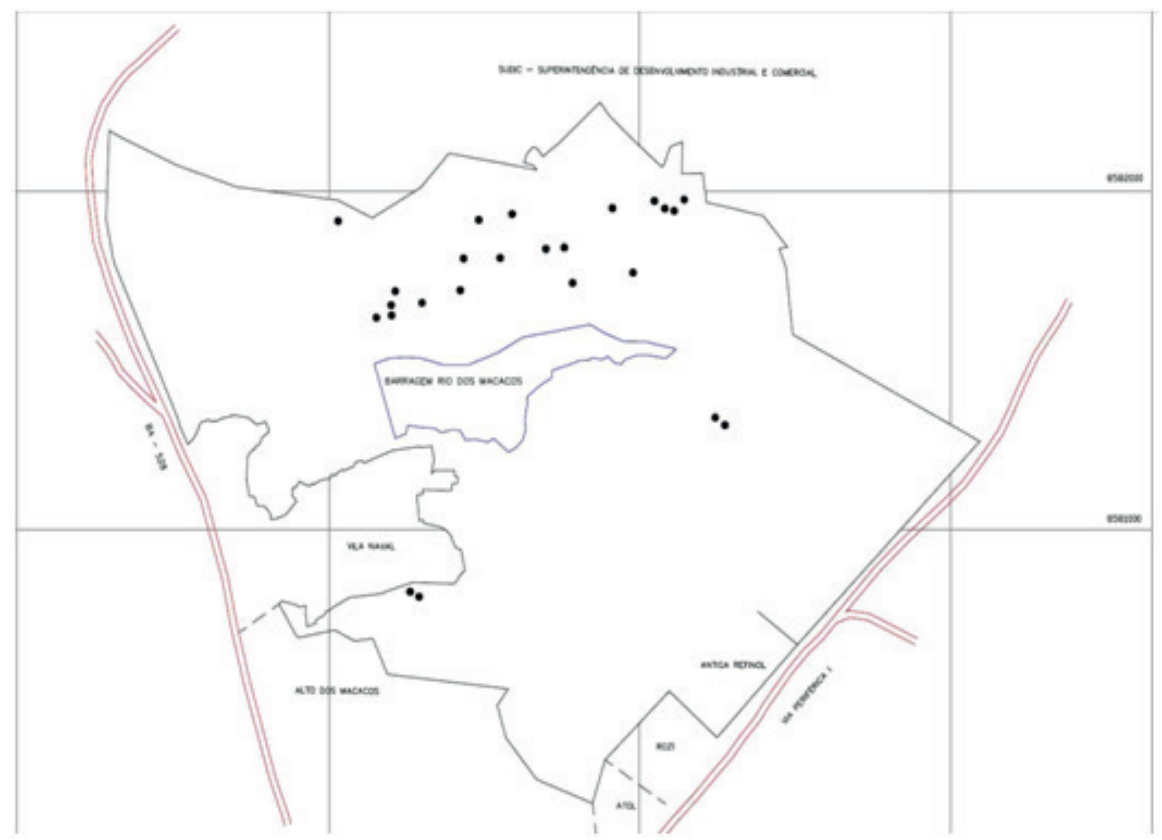

Fonte: Laudo Antropológico da Comunidade Quilombola Rio dos Macacos (2012)

\section{CONSIDERAÇÕES FINAIS}

O laudo antropológico aqui analisado mostrou como o processo de constituição dos grupos étnicos quilombolas no Brasil não foi homogêneo. Trata-se de um processo histórico e social complexo, que formou vários grupos sociais de ascendência negra, sobretudo no campo, em condições bastante peculiares, e que hoje demandam políticas públicas sob o rótulo de "remanescentes de quilombos". Mostrou como uma pesquisa etnográfica baseada na premissa de que não existem "sociedades sem história" pode fazer emergir uma historicidade endógena dos grupos quilombolas no Brasil. Este artigo procurou descrever essa pesquisa etnográfica, que teve a história como importante aliada, mas que não se submeteu passivamente ao historicismo e mostrou como a antropologia e a história podem se retroalimentar.

A partir da análise de uma situação etnográfica específica, num contexto de perícia antropológica, foi possível perceber como uma "antropologia da história" pode operar. Neste caso concreto, foi possível compreender como a própria atuação da Marinha do Brasil ao longo dos 
anos, geradora de vários conflitos socioterritoriais, fez emergir em Rio dos Macacos a identidade étnica quilombola do grupo. E também como a comunidade acionou, a partir dos seus vínculos territoriais, o seu "estoque cultural e histórico", assumindo/construindo uma identidade que a reposicionou num contexto de disputas. A categoria jurídico-política "quilombo" foi então acessada pela comunidade, como uma prática política e mais uma estratégia de resistência para sua manutenção naquele território.

Desta forma, o laudo ajudou a forjar, através da textualização, uma historicidade possível para Rio dos Macacos e pôde ser mais um instrumento importante da comunidade na construção de sua identidade social e política. O laudo tornou-se também, ele mesmo, um documento histórico que registrou um "outro passado" (PALMIÉ; STEWART, 2016) para os quilombolas de Rio dos Macacos, sendo, portanto, um locus privilegiado de pesquisa sobre uma antropologia da história.

\section{NOTAS}

1. É muito recorrente na literatura sobre este tema encontrarmos a denominação "laudo antropológico" para se referir ao produto de perícia antropológica feita por demanda do Poder Judiciário, para responder aos quesitos postos pelo juízo ou em juízo; ou por demanda do Ministério Público, para instrução de ações civis públicas. Já a denominação "relatório antropológico" estaria circunscrita ao produto de perícia (ou trabalho de campo) feita para atender demandas de órgãos do Poder Executivo, como o INCRA e a FUNAI. Contudo, muito embora as Instruções Normativas do INCRA utilizem a denominação "relatório antropológico", percebo que tanto o termo "relatório antropológico" como o termo "laudo antropológico" são utilizados corriqueiramente pelos antropólogos. Neste artigo fiz a opção por usar o termo "laudo antropológico", por entender que este é mais abrangente neste campo de atuação profissional e na literatura especializada.

2. O Instituto Nacional de Colonização e Reforma Agrária (Incra) é uma autarquia federal, cuja missão prioritária é executar a reforma agrária e realizar o ordenamento fundiário nacional. Criado pelo Decreto no 1.110 , de 9 de julho de 1970, atualmente o Incra está subordinado ao Ministério da Agricultura, Pecuária e Abastecimento (MAPA) e implantado em todo o território nacional por meio de 30 Superintendências Regionais (SR). Dentre as ações desenvolvidas pelo INCRA, temos: a desapropriação de imóveis rurais, a implantação do programa nacional de reforma agrária, a concessão de crédito instalação aos assentados, construção de infraestrutura nos assentamentos de reforma agrária, fomento a ações produtivas nos projetos de assentamento, gestão do programa de assistência técnica, social e ambiental aos projetos de assentamento, a titulação das áreas de reforma agrária, a gestão do programa de educação da reforma agrária, a gestão do cadastro rural, o georreferenciamento e a certificação dos imóveis rurais, controle da aquisição de terras por estrangeiros, a regularização fundiária na Amazônia Legal, e a regularização fundiária dos territórios quilombolas. 
3. De 2003 até hoje, o INCRA publicou 05 (cinco) Instruções Normativas regulamentando o Decreto 4.887/2003, promovendo várias alterações procedimentais. Foram as IN 16/2004, 20/2005, 49/2008, 56/2009 e 57/2009 (BRASIL, 2017).

4. Atualmente os laudos (ou relatórios) antropológicos são regulamentados pelo art. 10 da Instrução Normativa INCRA No 57/2009.

5. A Fundação Cultural Palmares é um órgão vinculado atualmente à Secretaria Especial da Cultura, que tem a função de certificar as comunidades quilombolas, nos termos do Decreto 4.887/2003.

6. Segundo a Marinha, a desocupação da área seria para a construção no local do grupamento de Fuzileiros Navais de Salvador, de uma unidade hospitalar, de um hotel de trânsito e novos Próprios Nacionais Residenciais para militares. Além disso, como as famílias ocupam a área no entorno da Barragem dos Macacos, estas estariam promovendo ações predatórias e poluindo as nascentes.

7. Na época, face a indisponibilidade de antropólogo (a) lotado (a) na Superintendência do INCRA na Bahia, a antropóloga do INCRA na Paraíba, Maria Ester Pereira Fortes, foi convocada para a elaboração do laudo. Esta antropóloga possui graduação em Ciências Sociais pela Universidade Estadual de Campinas (1997) e mestrado em Antropologia Social pela Universidade Estadual de Campinas (2004). É, desde 2006, analista em reforma e desenvolvimento agrário (com habilitação em antropologia) do INCRA.

8. Algumas considerações deste artigo foram apresentadas e publicadas inicialmente nos anais da IV Reunião Equatorial de Antropologia e XIII Reunião de Antropologia do Norte e Nordeste, ocorrida de 04 a 07 de agosto de 2013, em Fortaleza/CE, sob o título Conflitos Territoriais e Identidade Étnica: Uma Leitura do processo de Regularização Fundiária da Comunidade Quilombola Rio dos Macacos Bahia. Contudo, posteriormente, ele foi ampliado e objeto de novas análises, à luz das discussões e bibliografia da Disciplina “Antropologia e História”, ministrada pelo Professor Dr. Luís Nicolau Parés, semestre 2017.1, no Programa de Pós-Graduação em Antropologia da Universidade Federal da Bahia. Agradeço à antropóloga Maria Ester Pereira Fortes e ao Prof. Nailton Rocha pela leitura e contribuições ao texto.

9. O Relatório Técnico de Identificação e Delimitação (RTID) está previsto no Decreto 4.887/2003 e disciplinado atualmente pela Instrução Normativa INCRA No59/2009.

10. Cf. Ofício 002/2011 às fls. 02 do processo INCRA No54160.003162/2011-57.

11. Em novembro de 2010, o juiz federal responsável defere a tutela antecipada para determinar aos réus (34 moradores da comunidade) a desocupação das áreas, no prazo de 120 dias, sob pena de retirada compulsória

12. A área militar onde hoje funciona a Base Naval de Aratu, localizada na Baía de Todos os Santos, foi construída pelos EUA durante a Segunda Guerra Mundial. Após o término da guerra, a área foi transferida para a Marinha do Brasil e a Base Naval de Aratu entrou em funcionamento em $1^{\circ}$ de janeiro de 1970. Seu papel é de prover Apoio Logístico às Forças Navais, Aeronavais e de Fuzileiros Navais da Marinha do Brasil, estacionadas ou em trânsito na área do $2^{\circ}$ Distrito Naval (https://www.marinha.mil.br/bna/, acesso em 27/02/2020). Esta base naval tem sido frequentemente local de férias de Presidentes de República. A comunidade quilombola de Rio dos Macacos não se localiza dentro desta Base, mas nas suas proximidades, numa área onde foi 
construída a Barragem dos Macacos (que serve para abastecimento da Base Naval) e da Vila Naval da Barragem (condomínio onde residem os oficiais da Base Naval).

13. Em outubro de 2011, a Associação dos Remanescentes do Quilombo Rio dos Macacos solicitou atuação urgente do INCRA, o que resultou na instauração do processo administrativo de regularização fundiária ( $\mathrm{N}^{\circ}$ 54160.003162/2011-57).

14. Muito embora de acordo com a legislação em vigor (Decreto 4.887/2003 e Instrução Normativa INCRA/No57/2009), não seja esse o objetivo dos laudos antropológicos, a expectativa dos atores envolvidos com a questão quase sempre passa pela visão de que os laudos devem ser um documento de prova da condição quilombola dos grupos pesquisados.

15. Nora (1993) argumenta que haveria atualmente uma valorização pelos lugares onde a memória se cristaliza e se manifesta. Esses "lugares da memória" seriam para ele uma necessidade da modernidade, espaços de nostalgia, frente a uma sociedade marcada pela "aceleração da história". O processo de descolonização, mundialização, democratização, mediatização e massificação produz cada vez mais um passado morto, uma ruptura com o passado e um esfacelamento da memória. Os lugares de memória são espaços, locais onde a memória social é ancorada, revivida e apreendida pelos sentidos e funcionam como alicerces simbólicos desta memória coletiva. Eles são como arquivos vivos produzidos pelo sentimento que a memória não é espontânea nem natural. Esses locais revestem-se de uma importância como documentos ou monumentos, objetos ou fatos físicos ou simbólicos, que revelam a vontade de memória e representam a necessidade dos grupos sociais de encontrar suas origens, de buscar explicações para sua própria constituição.

16. Em 1961, houve o desmembramento da área do Engenho Aratu, que passou a pertencer ao município de Simões Filho.

17. Foi excluída da proposta de delimitação área correspondente à Vila Naval da Barragem, local de moradia dos oficias da Marinha, por se tratar de uma área de ocupação já consolidada.

18. A luta da Comunidade Quilombola Rio dos Macacos é hoje conhecida nacionalmente, sobretudo após a produção do filme "Quilombo Rio dos Macacos - O Filme", que pode ser visto no link: https://www.youtube.com/watch?v=-c0GXT1ICis.

19. Ver: <http://www.incra.gov.br/pt/territorio-quilombola-rio-dos-macacos-e-titulado-na-bahia.html>. Acesso em: 11 nov. 2020.

\section{REFERÊNCIAS}

ALMEIDA, Alfredo Wagner Berno de. Terras de quilombo, terras indígenas, "babaçuais livres", "castanhais do povo", faxinais e fundos de pasto: terras tradicionalmente ocupadas. Manaus: PPGSCA-UFAM, 2006.

AMOROSO, Marta; LIMA, Leandro Mahaken de. A aculturação é um objeto legítimo da Antropologia. Entrevista com Peter Gow. Revista de Antropologia, São Paulo, v. 54, n. 1, ago. 2012. ISSN 1678-9857. Disponível em: <https://www.revistas.usp.br/ra/article/view/38611/41458>. Acesso em: 10 ago. 2017. 
ARRUTI, José Maurício. O quilombo conceitual: Para uma sociologia do "artigo 68". Texto para discussão Projeto Egbé - Territórios Negros (KOINONIA), 2003.

ARRUTI, José Maurício. Mocambo: antropologia e história no processo de formação quilombola. Bauru: Edusc, 2006.

ASSOCIAÇÃO BRASILEIRA DE ANTROPOLOGIA - ABA. Documento do Grupo de Trabalho sobre Comunidades Negras Rurais (Rio de Janeiro, 17-18 de outubro de 1994). In: Boletim Informativo NUER Núcleo de Estudos sobre Identidade e Relações Interétnicas / Fundação Cultural Palmares - Florianópolis: UFSC, v. 1, n.1, p. 81-82, 1997.

BARTH, Fredrik. O Guru, o iniciador e outras variações antropológicas. Rio de Janeiro: Contra Capa Livraria, 2000.

BRASIL. Decreto $n^{\circ} 4.887$, de 20 de novembro de 2003. Regulamenta o procedimento para identificação, reconhecimento, delimitação, demarcação e titulação das terras ocupadas por remanescentes das comunidades dos quilombos de que trata o art. 68 do Ato das Disposições Constitucionais Transitórias. Brasília, 2003. Disponível em: <http://www.planalto.gov.br/ccivil_03/decreto/2003/d4887.htm>. Acesso em: 30 out. 2018. BRASIL. Ministério do Desenvolvimento Agrário. Instituto Nacional de Colonização e Reforma Agrária. Instrução normativa nº 57, de 20 de outubro de 2009. Regulamenta o procedimento para identificação, reconhecimento, delimitação, demarcação, desintrusão, titulação e registro das terras ocupadas por remanescentes das comunidades dos quilombos de que tratam o Art. 68 do Ato das Disposições Constitucionais Transitórias da Constituição Federal de 1988 e o Decreto no 4.887, de 20 de novembro de 2003. Brasília, 2009. Disponível em: <http://www.incra.gov. br/sites/default/files/uploads/institucionall/legislacao--/atos-internos/ instrucoes/in_57_2009_quilombolas. pdf>. Acesso em: 30 out. 2018.

CARDOSO DE OLIVEIRA, Roberto. Caminhos da Identidade: Ensaios sobre etnicidade e multiculturalismo. São Paulo: Editora UNESP; Brasília: Paralelo 15, 2006.

CUNHA, Manuela Carneiro da. Negros, estrangeiros: os escravos libertos e sua volta à África. São Paulo: Ed. Brasiliense, 1985.

CUNHA, Manuela Carneiro da. Cultura com Aspas e outros ensaios. São Paulo: Cosac Naify, 2009.

COMAROFF, Jean e John. "Etnografia e imaginação histórica”. Revista Proa, n. 2, v. 1, p. 1- 72, 2009.

DARNTON, Robert. "Os trabalhadores se revoltam: o grande massacre de gatos na rue Saint-Séverin”. In: O grande massacre de gatos: e outros episódios da história cultural francesa, Rio de Janeiro: Graal, 1988 [1984]. p. $103-140$.

FORTES, Maria Ester Pereira. Relatório Antropológico da Comunidade Quilombola Rio dos Macacos, Salvador/Simões - Bahia. Salvador: INCRA, 2012. (mimeo). 
FUNDAÇÃO CULTURAL PALMARES (FCP). Comunidades quilombolas, 2016. Disponível em: <http://www.palmares.gov.br/>. Acesso em: 15 ago. 2019.

GOLDMAN, Márcio. Lévi-Strauss e os sentidos da História. Revista de Antropologia, São Paulo, USP, v. 42, n. 1-2, p. 223-238, 1999.

GINZBURG, Carlo. História Noturna. Decifrando o Sabá. São Paulo: Companhia das Letras, 1991.

HALBWACHS, Maurice. A memória coletiva. São Paulo: Edições Vertice, 1990 [1968].

INSTITUTO NACIONAL DE COLONIZAÇÃO E REFORMA AGRÁRIA (INCRA). Disponível em: <www.incra.gov.br>. Acesso em: 11 abr. 2019.

LÉVI-STRAUSS, Claude. Antropologia estrutural. São Paulo: Cosac Naify, 2008.

LÉVI-STRAUSS. Claude. História e etnologia. 3. ed. Campinas: IFCH/ Unicamp, 2004.

LÉVI-STRAUSS, Claude. O Pensamento Selvagem. Campinas: Papirus, 1989.

LÉVI-STRAUSS, Claude. Raça e História. In: LÉVI-STRAUSS, Claude. Antropologia Estrutural II. Rio de Janeiro: Tempo Brasileiro, 1973.

NORA, Pierre. Entre História e Memória: a problemática dos lugares. Tradução de Yara Aun Khoury. Projeto História, São Paulo, n. 10, dez. 1993.

O’DWYER, Eliane Cantarino (org.). Terra de Quilombos. Rio de Janeiro: Associação Brasileira de Antropologia, 1995.

PALMIÉ, Stephan; STEWART, Charles. "Introduction for an anthropology of History". Hau: Journal of Ethnographic theory, v. 6, n. 1, p. 207 236, 2016.

REIS, João José; GOMES, Flávio dos Santos. Liberdade por um fio: História dos quilombos no Brasil. São Paulo: Companhia das Letras, 1996.

REIS, João José. Escravos e coiteiros no quilombo do Oitizeiro: Bahia, 1806. In: REIS, João José; GOMES, Flávio dos Santos (Org.). Liberdade por um fio: história dos quilombos no Brasil. São Paulo: Companhia das Letras, 1996.

RODRIGUES, Henrique Estrada. Lévi-Strauss, Braudel e o tempo dos historiadores. Revista Brasileira de História, São Paulo, v. 29, n. 57, p. 165-186, 2009.

SAHLINS, Marshall. Ihas de história. Rio de Janeiro: Jorge Zahar, 1990.

SCHWARCZ, Lilia K. Moritz. História e Etnologia. Lévi-Strauss e os embates em região de fronteira. Revista de Antropologia, São Paulo: USP, v. 42, n. 1-2, 1999.

SCHWARCZ, Lilia K. Moritz. Questões de Fronteira. Sobre Uma Antropologia da História. Novos Estudos, São Paulo, n. 72, jul. 2005. 
TRECCANI, Girolamo Domenico. Terras de Quilombo: Caminhos e entraves da titulação. Belém: Secretaria da Justiça, 2006. Disponível em: $<$ http://www.direito.caop.mp.pr.gov.br/arquivos/File/Girolamo.pdf >. Acesso em: 06 jun. 2012.

ZAGATTO, Bruna Pastro. Relatório Antropológico de identificação do território da comunidade quilombola Rio dos Macacos, Simões Filho, Bahia. Salvador: Zagatto Consultoria Ambiental e Social, 2012. 